УДК 811.161.1. 81'4

DOI 10.23951/1609-624X-2020-2-92-102

\title{
ДИСКУРСИВНАЯ СПЕЦИФИКА ИНЖЕНЕРНОЙ КОММУНИКАЦИИ В РУССКОМ СОЦИОКУЛЬТУРНОМ ПРОСТРАНСТВЕ
}

\author{
Н. В. Куркан ${ }^{1}$ Н. В. Фадеева, Н. А. Мишанкина ${ }^{1,2}$ \\ ${ }^{1}$ Национальный исследовательский Томский политехнический университет, Томск \\ ${ }^{2}$ Национальный исследовательский Томский государственный университет, Томск
}

\begin{abstract}
Введение. Рассматривается специфика коммуникации профессионального сообщества инженеров по отношению к научному дискурсу и специфика агента такой коммуникации как одной из наиболее важных областей современной жизни, обеспечивающей технологическое развитие промышленности, научный потенциал образования. Становление профессионального сообщества инженеров связывается с зарождением и развитием промышленности как общественного фактора: XIX в. сформировал, а XX в. упрочил позицию инженера так же, как когда-то были сформированы корпоративные сообщества медиков, юристов и т. п. Однако, в отличие от последних, инженерная корпорация еще не была изучена ни в аспекте рефлексии профессионального «образа», ни в аспекте коммуникативных практик. Частично тексты профессиональной коммуникации инженеров описаны в рамках научно-технического стиля, но как самостоятельный объект исследования она практически не выступала.

Материал и методы. Методологической основой работы послужили исследования в области когнитивнодискурсивной лингвистики: анализа дискурса, научного дискурса, исследования в области функциональной стилистики и жанрологии, профессионального языка и коммуникации, исследование структуры концепта. Результаты были получены с использованием методов: дискурс-анализа, текстологического, дефиниционного, компонентного и количественного анализа, данных ассоциативного словаря, анализа корпусных данных, данных поисковых систем. Материал исследования: данные энциклопедий, словарей, Национального корпуса русского языка, корпуса текстов стандартов.

Результаты и обсуждение. В работе решаются две проблемы: 1) определение границ профессиональной коммуникации инженеров как самостоятельной дискурсивной области, описание ее основных параметров в аспекте институциональности, обозначены границы по отношению к научному дискурсу: цели, участники, жанровый состав; 2) определение ключевого агента этой области профессиональной коммуникации: концептуальных границ понятия «инженер», ядром которого является представление о специалисте с высшим техническим образованием, а также соотношение с понятиями «инженерия», «инжиниринг». Обозначение профессиональной области «инженерия» актуализируется в связи с усложнением структуры профессиональной деятельности инженеров, включающей не только разработку и обслуживание новых технических объектов, но и их внедрение.

Заключение. Рассматриваемая долгое время как часть научно-технического дискурса инженерная коммуникация выделяется в общей системе институционального дискурса на основании определенных системообразующих параметров.
\end{abstract}

Ключевые слова: профессиональная коммуникаиия, инженерный дискурс, научный дискурс, жанр, агент коммуникации, инженер, инженерия, инжиниринг, конщептуальная структура.

\section{Введение}

Взаимодействие в профессиональных областях всегда было одной из наиболее значимых для общества форм социокультурной организации и стратификации. Профессия как вид деятельности занимает значительную часть жизни каждого члена социума и в количественном, и в содержательном плане. Более того, если человек не включен в профессиональное сообщество, то он как бы «не существует» для общества. По мнению Е. И. Головановой, «профессиональная деятельность выступает составной частью культуры этноса, она аккумулирует особенности данной культуры и вместе с тем формирует ее специфику» [1, с. 229]. В этой связи следует признать, что профессиональная коммуникация представляет собой значительную часть речевых практик современного человека и основу национальной культуры. В настоящее время профессиональная коммуникация понимается как система речевых практик в социально-профессиональной области, которая объединяет носителей языка, принадлежащих к профессиональному сообществу, и соответствует требованиям профессионального взаимодействия (целям, системе профессиональных знаний) [2].

В связи со значимостью профессиональной деятельности в целом социальный имидж профессионального сообщества - одна из главных его задач, так как формирование позитивного образа профессии, повышение социального статуса влечет за собой доступ к ресурсам, дает возможность оказывать влияние на общество. Имидж профессии мо- 
жет изменяться с течением времени как результат работы сообщества в этом направлении либо под давлением внешних обстоятельств. Важность имиджа профессии активно рефлексируется в социологических и исторических исследованиях. Например, в работе немецкого историка С. Шаттенберг «Инженеры Сталина: Жизнь между техникой и террором в 1930-е годы» представлен репрезентативный обзор литературных, кинематографических, газетных источников, отразивших смену идеологического взгляда на профессиональное сообщество инженеров. С. Шаттенберг последовательно показывает трансформации корпоративной символики, этики, традиций инженерного образования и специфики профессиональной деятельности, формируя из обломков технической интеллигенции нового «советского инженера». Автор пишет о последовательном уничтожении инженеров старой формации путем создания «дискурса о вредителях» в прессе, литературе и кино и формировании «инженера нового типа», над положительным образом которого работают лучшие представители творческой интеллигенции [3].

Вариант общенационального языка, используемый в профессиональной коммуникации, имеет в литературе различные наименования: корпоративный, профессиональный, специальный язык/подъязык, язык для специальных целей, что во многом свидетельствует о явно недостаточном уровне исследовательской рефлексии и разработанности данной проблематики.

Первоначально исследовательские интересы в области изучения фокусировались в описании собственно профессиональной части - описании терминосистем отдельных дисциплин (Д. С. Лотте, А. А. Реформатский, В. В. Виноградов, А. С. Гердт, М. В. Лейчик, Л. А. Капанадзе, Т. Л. Канделаки, В. Н. Прохорова, Е. И. Голованова, О. В. Фельде и многие другие). Затем акцент был перенесен на изучение социальных аспектов профессиональной коммуникации (Э. В. Гафиятова, Е. И. Голованова, А. С. Кобыскан, В. П. Коровушкин, Л. З. Подберезкина, М. И. Солнышкина, Т. Н. Хомутова).

В последнее время одним из наиболее продуктивных подходов считается дискурсивный, синтезирующий собственно лингвистические, социальные, культурные и исторические аспекты взаимодействия, позволяющий взглянуть на профессиональную коммуникацию именно как на систему речевых (дискурсивных) практик. Однако появляются новые исследовательские проекты, направленные на изучение профессиональных сообществ в дискурсивном аспекте. К наиболее изученным в российской лингвистике можно отнести коммуникацию в медицине и юриспруденции (Л. С. Бейлинсон, Л. А. Борисова, Н. А. Дзараева, О. В. Косоно- гова, Е. А. Костяшина, Л. А. Нефедова, Э. Ш. Никифорова, Р. А. Рогожникова, К. А. Устинова, Л. С. Шуравина, М. И. Барсукова, В. В. Жура), в рамках педагогики (Н. Б. Буртова, Н. А. Воробьева, Т. П. Вострикова, И. К. Гаврилова и др.).

Профессиональная коммуникация инженеров в силу своего динамичного развития, определяемого стремительным развитием технологий, также начинает привлекать внимание лингвистов. Становление профессионального сообщества инженеров связывается с зарождением и развитием промышленности как общественного фактора: XIX в. сформировал, а XX в. упрочил позицию инженера так же, как когда-то были сформированы корпоративные сообщества медиков, юристов и т. п. Однако, в отличие от последних, инженерная корпорация еще не была изучена ни в аспекте рефлексии профессионального «образа», ни в аспекте коммуникативных (дискурсивных) практик. Причина этого видится в том, что при преобладающем в отечественной лингвистике подходе к ней как к разновидности научного (или научно-технического) дискурса/стиля проблемы ее выделения в отдельную дискурсивную структуру практически не ставились: как самостоятельная область социально-речевой деятельности инженерная коммуникация подробно исследуется только в работах А. Б Авдеевой [4], Л. И. Ивановой [5], Г. М. Лёвиной [6] в лингводидактическом аспекте.

На первом этапе определения параметров профессиональной коммуникации инженера необходимо уточнить два аспекта: 1) специфику коммуникации профессионального сообщества инженеров по отношению к научному дискурсу и собственные дискурсивные параметры; 2) специфику агента такой коммуникации, а именно содержание и структуру понятия «инженер» и смежных с ним. Именно это и является целью данного исследования.

\section{Материал и методы}

Методологической основой работы послужили исследования в области когнитивно-дискурсивной лингвистики: анализа дискурса [7-9], научного дискурса [10-12], исследования в области функциональной стилистики и жанрологии [13-14], профессионального языка и коммуникации $[1-2,15]$, исследование структуры концепта [16-19].

В ходе анализа применялись следующие методы и приемы:

а) при определении дискурсивных параметров профессиональной коммуникации инженеров были задействованы дискурс-анализ, приемы текстологического и количественного анализа;

б) при описании концептуальной структуры был использован дефиниционный, компонентный 
текстологический и количественный анализ, анализ ассоциатов, анализ корпусных данных, анализ данных поисковых систем.

Материалом исследования послужили: 1) корпус текстов стандартов (21 стандарт); 2) словарные данные (см. список источников); 3 ) данные Национального корпуса русского языка (2 994 документа); 4) данные, полученные с помощью поисковых систем сети Интернет Google.ru, Yandex.ru, Rambler.ru.

\section{Коммуникативные параметры профессионального взаимодействия инженеров}

Определение особенностей инженерной коммуникации, позволяющих говорить о ней как об отдельном виде дискурса, требует определения понятия институционального дискурса и его основных критериев. В. И. Карасик интерпретирует институциональный дискурс как «общение, ограниченное рамками статусно-ролевых отношений» [7, с. 292]. Используя идею В. И. Карасика о том, что институциональный дискурс выделяется на основании таких системообразующих признаков, как цели и участники общения, ценности, стратегии, тематика, жанры, дискурсивные формулы, покажем, что инженерная коммуникация является самостоятельным видом профессионального дискурса. Е. И. Голованова, разделяя точку зрения на профессиональный дискурс как на институциональный, дает его определение: «Под профессиональным дискурсом мы предлагаем понимать вербально опосредованную коммуникацию как процесс контролируемого взаимодействия субъектов профессиональной деятельности, характеризующийся определенным комплексом норм, стереотипов мышления и поведения» [2, с. 32].

В связи с тем что ранее тексты, относящиеся к профессиональной коммуникации инженеров, частично рассматривались в рамках научно-технического подстиля научного дискурса, попытаемся определить дискурсивную специфику этой формы коммуникации на его фоне.

Различие в целях и задачах деятельности инженера и ученого обусловливает специфику коммуникации. Цель науки - выработка «объективных, системно организованных и обоснованных знаний о действительности» [20, с. 877]. Основной же целью деятельности инженера является разработка, производство и обслуживание искусственных объектов при помощи научных методов, соответственно, целью инженерной коммуникации следует считать решение производственных задач, оптимизацию технологий, их практическое применение и контроль производственных процессов.

Говоря об участниках дискурса, отметим, что схема «агент - клиент» [7] в случае профессио- нальной коммуникации инженеров требует некоторого уточнения. Причиной этого является сложность и многоплановость современных инженерных задач, решение которых требует взаимодействия инженеров различных направлений. Поэтому участвуя в профессиональной коммуникации в качестве агентов, инженеры выполняют различные роли: инженера-разработчика (проектировщика, конструктора, дизайнера), т. е. профессионалов, которые обеспечивают интеллектуальную поддержку процесса создания продуктов и технологий, инженера-эксплуататора, ответственного за управление технологиями и их мониторинг, инженераменеджера, задача которого состоит в убеждении клиентов/аудитории в преимуществах разработанной или усовершенствованной технологии путем преобразования сложных данных о представляемом продукте в интересную информацию, доступную для понимания большинства.

Участники научного дискурса - ученые, являющиеся представителями различных научных сообществ [11, с. 72], менее дифференцированы с точки зрения выполняемых задач.

Клиентами в рамках профессиональной коммуникации инженеров выступают как профессионалы в этой области, так и непрофессионалы. К «профессиональным» клиентам относятся прежде всего инженеры, занятые в той же или смежной сфере, ученые, результаты научной деятельности которых могут напрямую зависеть от используемых приборов, а также и начинающие свою профессиональную деятельность выпускники инженерных вузов. Клиенты-непрофессионалы - это представители делового сообщества, заинтересованные в получении прибыли от продажи новых технологий - спонсоры, представители торговых организаций. К этой группе клиентов также относится и публика потребительского общества, интересующаяся информацией об инженерных разработках.

Окончательным результатом инженерной деятельности является создание продукта и/или технологии его производства, и критерий качества этих разработок заключается в соответствии определенным стандартам, что позволяет определить стратегии профессиональной коммуникации инженеров: 1) поставить задачу; 2) выбрать методы решения/исследования задачи; 3 ) получить варианты решения задачи; 4) оценить варианты решения и выбрать оптимальный; 5) реализовать выбранное решение в виде готового продукта.

В. И. Карасик предлагает рассматривать в качестве ценностей научного дискурса знание, истину и исследование [7, с. 28]. В работе Н. А. Мишанкиной уточняется, что в качестве ценностей могут выступать критерии научности: систематичность, 
методичность, критичность и общезначимость результатов [11, с. 75-78].

Ценностями профессиональной коммуникации инженеров, то есть тем, что представляет значимость, мы можем назвать технический прогресс как совершенствование знаний о достижимых технических возможностях [21], технологическую эффективность как уровень организации производства с максимально рациональным использованием ресурсов и утилитарность как направленность на пользу, решение прагматических технологических задач.

Специфика решений современных инженерных задач состоит в объединении и сотрудничестве специалистов разных научных и технических профилей, что отражается в профессиональной коммуникации:

1) тематика современного инженерного дискурса соответствует направлениям инженерной деятельности ;

2) формулируются проблемы, затрагивающие одновременно разные сферы инженерной деятельности, например, темы, касающиеся разработок программной инженерии, робототехники.

Речевые практики, принятые в дискурсе, реализуются в определенных жанрах. Во многих работах [7, 10-13, 22,] представлена классификация жанров научного дискурса: академические; научно-информационные; научно-критические; научно-популярные; научно-учебные. Обозначенные жанры также характерны для профессиональной коммуникации инженеров, но могут быть рассмотрены только в качестве периферийных, находящихся на границе взаимодействия с другими дискурсами: научным, педагогическим.

В инженерной коммуникации присутствуют жанры, которые в силу своих характеристик не могут быть отнесены к научным или даже к научнотехническим. Такие жанры, как стандарты, инструкции, патенты, различного рода технические описания и пр., представляют цели профессиональной коммуникации инженеров - решение производственных задач и оптимизацию технологий наиболее последовательно, поэтому рассматриваются как ядерные. Несмотря на то, что в названных жанрах присутствует точное определение понятий, логичность, последовательность изложения, насыщенность фактической информацией, они не содержат научной тематики - главного признака научной коммуникации, следовательно, не могут входить в число ядерных жанров научного дискурса.

Язык инженерной коммуникации традиционно рассматривался в русле методологии функцио-

${ }^{1}$ См. спектр профессиональных областей, представленный в следующем разделе по корпусным данным. нальной стилистики как научно-технический подстиль научного стиля [13]. Поэтому при всем разнообразии жанров профессиональной коммуникации инженеров присущи специфические черты данного подстиля: 1) однозначность, исключающая возможность иных толкований; 2) логичность, заключающаяся в последовательной организации текста, направленная на максимальную эксплицированность знания о технологии; 3) нейтральность, отсутствие субъективного начала, неэкспрессивность. Эти черты находят свое выражение в первую очередь в выборе языковых средств для ядерных жанров (стандарта, инструкции), в том числе и дискурсивных формул - особых слов и словосочетаний, характерных для употребления представителями в рамках определенного института [7, 9]. Для профессиональной коммуникации инженеров такими прежде всего являются:

- технические термины, обозначающие как понятия из области физических явлений, так и оборудование или его детали, вещества, продукты производства: трубы стальные электросварные прямошовные, сплавы медно-ичинковые, осциллографы смешанных сигналов;

- аббревиатуры, сокращения и буквенно-цифровые обозначения терминологического характера: ISO (International Standard Organisation), ГОСТ, монитор VGA (video graphic adapter), приборы серии DPO4000B (digital phosphor oscilloscope);

- нормативные ссылки - перечень международных, государственных, межотраслевых стандартов, на которые в тексте даны ссылки: ГОСТ Р 1.7-2014 Стандартизация в РФ. Стандарты национальные; ОК (МК (ИСО/ИНФКО МКС) 001-96) 001 Общероссийский классификатор стандартов; МЭК 60061 Цоколи и патроны для ламп...;

- текстовые клише, характерные для ядерных жанров: «...введен в действие в качестве стандарта приказом Федерального агентства..», «настоящий стандарт распространяется на ...», «прибор не предназначен для...», «Шаг 1.. Шаг 2... и пр.

Таким образом, полагаем, что перечисленные параметры позволяют рассматривать профессиональную коммуникацию инженеров как отдельный вид институционального профессионального дискурса, отличного от научного. В этой связи мы сочли необходимым более детально взглянуть на ключевого агента этого вида профессиональной коммуникации в аспекте его отражения в семантике языковых единиц.

\section{Агент коммуникации: содержание и структура понятия «инженер»}

Предварительный анализ показал, что область этой профессиональной деятельности в русском языке не имеет устойчивой номинации. Нам уда- 
лось выявить несколько теперь уже устаревших и редко используемых обозначений: инженерное дело, инженерство. В современном русском языке функционируют лексемы инженерия, инжиниринг. Однако наиболее частотна лексема, номинирующая лицо по профессии - инженер.

Понятие «инженер» пришло в русский язык из французского вместе с заимствованием ingénieur (от лат. ingenium - способность, творить, изобретательность) в значении «специалист, который работает с военными машинами» в XVII в. Широкое распространение профессии инженер в России происходит в начале XVIII в., когда в 1701 г. в Москве открылась школа математических и навигационных наук [23]. Именно с этого момента в России и началось инженерное образование.

Анализ энциклопедических и словарных статей позволил выявить, что в «Советском энциклопедическом словаре» словарные статьи «инженер», «инженерия», «инжиниринг» отсутствуют, но есть статьи, посвященные отдельным направлениям инженерной деятельности: инженерной геологии, $u$. гидравлике (гидравлика сооружений), и. психологии, и.-авиационной службе в ВВС СССР, и. войскам [20].

Лингвистические источники демонстрируют иные данные. Лексема инженер представлена уже в лексике XVII в. в значении «специалист по военной технике, по осаде крепостей, зашите или укреплению различных мест». Этот же источник содержит производные единицы инженерныли, инженерский и инженерство («Инженерная наука») [24].

В более поздних словарях можно наблюдать трансформацию семантической структуры лексемы инженер:

- словарь В. И. Даля: «ученый строитель, но не жильх домов (это архитектор, зодчий), а других сооружений различного рода» [25];

- словарь А. Н. Чудинова: «(фp. ingenieur, om лат. Ingenium - остроумное изобретение). Человек, изучающий это искусство» [26];

- словарь Д. Н. Ушакова: «Лицо с высшим техническим образованием» [27];

- словари С. И. Ожегова [28], МАС [29], С. А. Кузнецова [30], Л. П. Крысина [31]: «Специалист с высшим техническим образованием».

Лексемы инженерия, инжиниринг представлены реже и только в современных толковых словарях.

Инженерия:

MAC маркирует эту единицу как устаревшую, при этом второе значение показывает, что данная лексема является словообразовательным вариантом более ранней единицы: «Устар. Инженерное искусство, инженерное дело. 2. собир. Разг. устар. То же, что инженерство (во 2 знач.)» [29].
Русский семантический словарь [32] и Новый словарь иностранных слов [33] дают лексему инженерия без помет даже по отношению к первому ее значению. Однако при этом фиксируют при этом новое: «1. Инженерное дело, творческая инженерная деятельность. 2. В некоторых сочетаниях: Область знаний, относящихся к конструированию новых, не существующих в природе органических единиц; соответствуюшая отрасль практической деятельности (спец.). Клеточная и. (конструирование клеток нового типа)».

Лексема инжиниринг встречается еще реже и только в словарях, представляющих новейшую заимствованную лексику и терминологию. Оно вводится как заимствование из английского в значении «предоставление услуг по доведению новых идей (НИОКР - научно-исследовательских и опьгтно-конструкторских разработок) до стадии производства» [21]. Можно сделать вывод, что понятие «инжиниринг» у́же понятия «инженерия» и номинирует итоговый этап по внедрению инженерной разработки.

Итак, словарные данные показывают, что эта профессиональная деятельность связана в первую очередь с деятелем, ее реализующим: наиболее последовательно словари отражают лексему инженер. Понятие «инженер» с момента своего заимствования претерпевает значительные изменения: от номинации профессионала в области военной техники (XVII в.) до наименования человека, имеющего высшее техническое образование.

Значимыми при исследовании концептуальной структуры являются данные «Русского ассоциативного словаря» [34] как отражающие актуальное знание носителей русского языка. Обращение к этому источнику показало, что стимул инженер при прямом поиске дает 107 реакций, связанных с обозначением профессиональной области/ должности: конструктор, строитель, механик, технолог, экономист, электрик, главный. Остальные реакции связаны с периферийными компонентами значения лексемы, граничащими с коннотативной зоной: плохой, хорошиц̆, бедныци, зарплаma, зарплата в рублях. При обратном запросе получена 171 реакция, где основными также являются лексемы, маркирующие профессиональную область/должность: главный, конструктор, технолог, военнылй, горныци, специилист, профессия и т. п. Лексемы инженерия и инжиниринг отсутствуют в словнике, что свидетельствует о ядерном положении лексемы инженер в исследуемой структуре. Анализ ассоциативных реакций позволил также обозначить и уточнить основные виды профессиональной деятельности инженера. Это довольно широкий спектр специальностей, который принято обозначать как «технические», но 
они представляют собой очень разные профессиональные направления (ср. строитель и экономист).

Результаты, подтверждающие соотношение исследуемых понятий, показал анализ данных Национального корпуса русского языка [35] (поиск по всему корпусу). Лексема инженер встречается в 2994 документах (7 533 вхождений). Анализ выборки из 500 документов показал 120 различных употреблений лексемы инженер и словосочетаний, ее включающих, наиболее частотные приведены на рис. 1.

Единичные употребления (108) также имеют уточняющий характер: инженер-мостостроитель, инженер-физик, инженер-геолог, инженер-кораблестроитель и т. д.

Лексема инженерия представлена лишь в 67 документах (82 вхождения). Наиболее частотно употребление словосочетания генная инженерия (33). Самостоятельное употребление лексемы инженерия составляет 16 случаев. Номинации направлений инженерии единичны.

Употребление лексемы инжиниринг встречается еще реже - в 44 документах (60 вхождений). Самостоятельное употребление слова инжиниринг (20); в названиях фирм и предприятий: строчтельной, компьютерной и т. д. (23).

Таким образом, данные НКРЯ убедительно показывают, что ядром концептуальной структуры выступает понятие «инженер», а «инженерия» и «инжиниринг» составляют его периферию. При этом корпусные данные также позволяют уточнить понятийную структуру в аспекте состава специ- альностей: типичный инженер - это инженер-механик, инженер, связанный с созданием и обслуживанием технических устройств.

Н. Д. Голев в статье «Поисковые системы как лингвистический источник» говорит о том, что поисковые системы сети Интернет обладают бо́льшей квантитативной мощностью по сравнению с известными частотными словарями. Неизбежный информационный шум компенсируется огромными количественными показателями, позволяющими выявлять и описывать «объективные тенденции в языке и речи» [36, с. 197]. На этом основании мы сочли возможным обратиться к работе с поисковыми системами для получения самых актуальных данных о функционировании исследуемых единиц.

Полученные результаты по их функционированию отражены на рис. 2.

Итак, результаты позволяют сделать заключение о том, что ближе всего к результатам, полученным на основе словарных и корпусных данных, результаты, выданные поисковой системой Google здесь очевидно преобладание документов, включающих лексему инженер. Эта система также показывает очевидное количественное преобладание лексемы инжиниринг по сравнению с инженерией. Однако данные, полученные с помощью других систем, убедительно демонстрируют, что в современных текстах, представленных в Интернете, лексема инжиниринг используется почти в два раза чаще, чем инженерия. При этом и та и другая единица значительно чаще, нежели лексема инженер, по данным поисковых систем Yandex и Rambler.

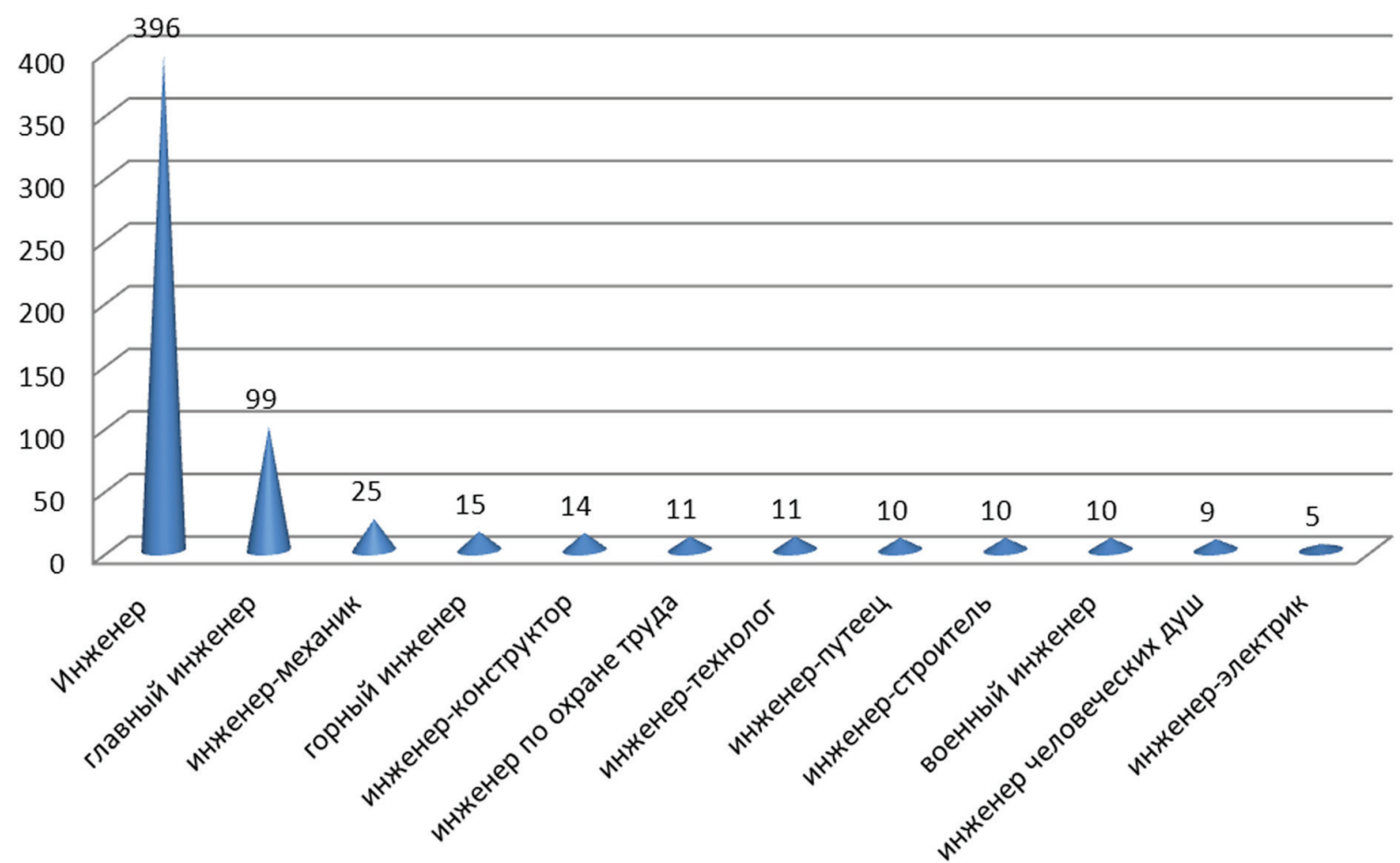

Рис. 1. Соотношение частотности лексемы инженер и словосочетаний с нею в Национальном корпусе русского языка (НКРЯ) 


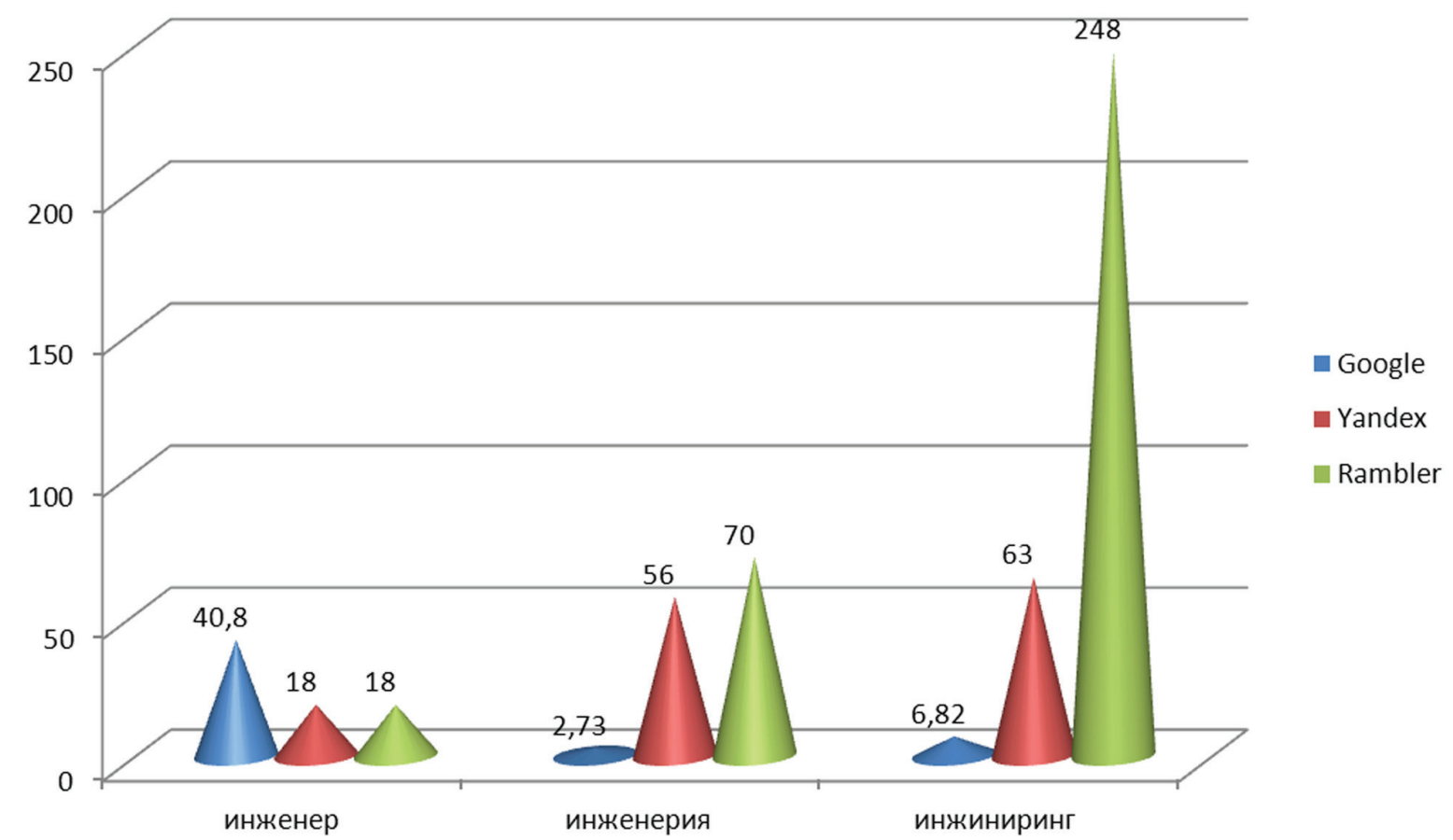

Рис. 2. Количественные данные о функционировании лексем инженер, инженерия и инжинирине, полученные с помощью поисковых систем Интернета (в млн словоупотреблений)

Таким образом, привлечение различных источников позволяет констатировать трансформацию концептуальной структуры понятия как в аспекте компонентов, ее формирующих, так и в аспекте изменения позиций ядерной и периферийной частей. Агентом коммуникации в исследуемом профессиональном сообществе является инженер - человек, имеющий высшее техническое образование.

\section{Заключение}

Проведенный анализ позволил сделать следующие выводы.

1. Рассматриваемая долгое время как часть научно-технического дискурса инженерная коммуникация выделяется в общей системе институционального дискурса на основании таких системообразующих параметров, как:

- основные цели - решение производственных задач;

- основные ценности - технический прогресс, эффективность, утилитарность;

- основные стратегии - постановка задачи, peaлизация решений в виде готового продукта;

- специализированная тематика профессиональной коммуникации;

- ядерные жанры - стандарт, инструкция и др.;

- доминирующие участники - инженеры-разработчики, инженеры-эксплуататоры.

2. В центре исследуемой концептуальной структуры находится понятие «инженер», которое является ключевым. Анализ словарных и корпусных данных показывает, что в языковой картине мира формируется восприятие этого вида деятельности через представления о человеке, участвующем в нем. Толкование лексемы «инженер» в основном в словарях различных временных периодов показывает трансформацию понятия, связанную с развитием этого вида профессиональной деятельности.

3. Анализ данных ассоциативного словаря и НКРЯ позволяет заключить, что обобщающее понятие «инженер» в настоящее время используется для обозначения целого круга профессиональных областей, таких как: механика, строительство, корабле-, авто-, самолетостроение, информационные технологии, программирование, физика, электри$\kappa a$, химия и др. Связано это с активным развитием научно-технического знания, появлением новых научных и профессиональных областей и постоянно усиливающейся специализацией в этой сфере.

4. Обозначение профессиональной области в целом или одного из ее видов («инженерия» «инжиниринг») появляется гораздо позже и актуализируется в связи с усложнением структуры профессиональной деятельности инженеров, включающей не только разработку и обслуживание новых технических объектов, но и их внедрение. Появление новых значений слова инженерия связано с возникновением новых научных областей, таких, например, как «генная инженерия».

5. Данные, полученные с помощью поисковых систем Интернета, показывают, что в настоящий момент времени использование лексем инженерия инжиниринг гораздо более частотно, нежели инженер. 


\section{Список литературы}

1. Голованова Е. И. Категория профессионального деятеля: Формирование. Развитие. Статус в языке. Челябинск: Челяб. гос. ун-т, 2004. $330 \mathrm{c}$.

2. Голованова Е. И. Профессиональный дискурс, субдискурс, жанр профессиональной коммуникации: соотношение понятий // Вестн. Челябинского гос. ун-та. Филология. Искусствоведение. 2013. № 1 (292). Вып. 73. С. 32-35.

3. Шаттенберг С. Инженеры Сталина: Жизнь между техникой и террором в 1930-е годы // Портал «ВикиЧтение». URL: https://history. wikireading.ru/260788 (дата обращения: 12.11.2018).

4. Авдеева И. Б. Инженерная коммуникация как самостоятельная речевая культура: когнитивный, профессиональный и лингвистический аспекты (теория и методика обучения русскому языку как иностранному). М.: Изд-во МГТУ им. Н. Э. Баумана, 2005. 367 с.

5. Иванова Л. И. Электронный сетевой иноязычный инженерный дискурс и его лингводидактические возможности // Известия ЮФУ. Технические науки. 2010. № 10 (111). С. 72-75.

6. Лёвина Г. М. Обучение иностранцев русскому инженерному дискурсу как одной из составляющих профрессионального образования в российских технических вузах: дис. ... д-ра пед. наук. М., 2004. 369 с.

7. Карасик В. И. Языковой круг: личность, концепты, дискурс. Волгоград: Перемена, 2002. 477 с.

8. Дейк Т. А. ван. Язык. Познание. Коммуникация: пер. с англ. / сост. В. В. Петрова. М., 1989. 312 с.

9. Квадратура смысла: Французская школа анализа дискурса: пер. с фр. и португ. / общ. ред. и вступ. ст. П. Серио; предисл. Ю. С. Степанова. М.: ОАО ИГ «Прогресс», 1999. 416 с.

10. Чернявская В. Е. Интерпретация научного текста. М.: КомКнига, 2006, 128 с.

11. Мишанкина Н. А. Метафора в науке: парадокс или норма? Томск: Изд-во Том. ун-та, 2010. 281 с.

12. Чернявская В. Е. Коммуникация в науке: нормативное и девиантное. Лингвистический и социокультурный анализ. М.: УРСС, Либроком, 2011. $270 \mathrm{c}$.

13. Кожина М. Н. Стилистика русского языка. М.: Просвещение, 1977. 223 с.

14. Шмелева Т. В. Жанроведение? Генристика? Генология? // Антология речевых жанров: повседневная коммуникация. М., 2007. С. $62-67$.

15. Голованова Е. И. Типология единиц профессиональной коммуникации: когнитивно-прагматический аспект // Вестн. Челябинского гос. ун-та. 2008. № 9. С. 25-28.

16. Фрумкина Р. М. Концептуальный анализ с точки зрения лингвиста и психолога // Научно-техническая информация. Сер. 2. Информационные процессы и системы. 1992. № 3. С. 1-9.

17. Гофман О. В. К вопросу о методе концептуального анализа // Картина мира: модели, методы, концепты. Томск: Изд-во ТГУ, 2001. C. 213-217.

18. Попова 3. Н., Стернин И. А. Когнитивная лингвистика. М.: АСТ: Восток-Запад, 2007. 226 с.

19. Смирнова О. М. К вопросу о методологии описания концептов // Вестник Нижегородского ун-та им. Н. И. Лобачевского. Филология. Искусствоведение. 2009. № 3. С. 247-253.

20. Советский энциклопедический словарь / гл. ред. А. М. Прохоров. 4-е изд. М.: Сов. энциклопедия, 1988. 1600 с.

21. Блэк Д. Экономика. Толковый словарь. М.: Инфра-М: Весь мир, 2000. 840 с.

22. Розенталь Д. Э. Практическая стилистика русского языка. М.: Высш. шк., 1987. 399 с.

23. Коробейников В. В., Коробейников А. В. Двадцатый век в биографии инженера: устная история в сопровождении документов // Иднакар: методы историко-культурной реконструкции. Ижевск: Знак Ижевск, 2010. 146 с.

24. Словарь русского языка XI-XVII вв. / гл. ред. С. Г. Бархударов; Академия наук СССР. Институт русского языка. М.: Наука, 1975. Вып. 6 (Зипунъ - Иянуарий). М: Наука. 1979, 359 с.

25. Даль В. И. Толковый словарь живого великорусского языка: в 4 т. 2-е изд. СПб.: Типография М. О. Вольфа, 1880-1882.

26. Словарь иностранных слов, вошедших в состав русского языка / под. ред. А. Н. Чудинова. СПб.: Изд. книгопродавца В. И. Губинского, Типография С. Н. Худекова, 1894. 1004 с.

27. Толковый словарь русского языка / под ред. Д. Н. Ушакова. М.: Гос. ин-т Сов. энцикл.: ОГИЗ: Гос. изд-во иностр. и нац. слов, 1935-1940 (4 т.).

28. Ожегов С. И. Словарь русского языка. Изд.10-е, стереотип / под ред. д-ра филолог. наук проф. Н. Ю. Шведовой. М: Сов. энциклопедия. 1973. $846 \mathrm{c}$.

29. Словарь русского языка: в 4 т. / РАН, Ин-т лингвистич. исследований; под ред. А. П. Евгеньевой. 4-е изд., стер. М.: Рус. яз.: Полиграфресурсы, 1999. Т. 1. А-Й. 702 с.

30. Кузнецов С. А. Большой толковый словарь русского языка. СПб.: Норинт, 2000. 1536 с.

31. Крысин Л. П. Толковый словарь иностранных слов. 2-е изд., доп. М.: Рус. яз., 2000. 856 с.

32. Русский семантический словарь. Толковый словарь, систематизированный по классам слов и значений / под общ. ред. Н. Ю. Шведовой. Т. 3: Имена существительные с абстрактным значением: Бытие. Материя, пространство, время. Связи, отношения, зависимости. Духовный мир. Состояние природы, человека. Общество. М.: Азбуковник, 2003. 720 с.

33. Захаренко Е. Н., Комарова Л. Н., Нечаева И. В. Новый словарь иностранных слов: свыше 25000 слов и словосочетаний. М.: ООО ИФ «Азбуковник», 2008. 1040 с. 
34. Русский ассоциативный словарь / Ю. Н. Караулов, Г. А. Черкасова, Н. В. Уфиимцева и др.: в 2 т. M., 2002. URL: http://www.tesaurus.ru/dict/ index.php (дата обращения: 15.03.2018).

35. Национальный корпус русского языка. URL: http://www.ruscorpora.ru/ (дата обращения: 05.03.2018).

36. Голев Н. Д. Поисковые системы Интернета как лингвистический источник (на примере решения некоторых теоретических и прикладных вопросов русского словообразования) // Новые явления в славянском словообразовании. Система и функционирование. М.: Изд-во Московского ун-та, 2010. С. 197-212.

Куркан Наталия Владимировна, аспирант, Национальный исследовательский Томский политехнический университет (пр. Ленина, 30, Томск, Россия, 634050). E-mail: kurkan@tpu.ru

Фадеева Наталья Васильевна, аспирант, Национальный исследовательский Томский политехнический университет (пр. Ленина, 30, Томск, Россия, 634050). E-mail: ladonadums@gmail.com

Мишанкина Наталья Александровна, доктор филологических наук, профессор, Национальный исследовательский Томский политехнический университет (пр. Ленина, 30, Томск, Россия, 634050), Национальный исследовательский Томский государственный университет (пр. Ленина, 36, Томск, Россия, 634050). E-mail: mna@tpu.ru

Материал поступил в редакциию 04.07.2019.

DOI 10.23951/1609-624X-2020-2-92-102

\title{
DISCOURSIVE SPECIFICITY OF ENGINEERING COMMUNICATION IN THE RUSSIAN SOCIO-CULTURAL SPACE
}

\author{
N. V. Kurkan ${ }^{1}$, N. V. Fadeyeva ${ }^{1}$, N. A. Mishankina ${ }^{1,2}$ \\ ${ }^{1}$ National research Tomsk Polytechnic University, Tomsk, Russian Federation \\ ${ }^{2}$ National research Tomsk State University, Tomsk, Russian Federation
}

The article discusses the communication specifics of engineering society in relation to the scientific discourse. It also studies the special features of the agent in the engineering communication as one of the key areas of modern life which provides the technological progress of industry as well as the research potential for education. The rise of the engineering professional society was due to the introduction and development of industry as a social force. 19th century introduced the position of the engineer which was strengthened in 20th century in the same way as the corporate societies of other specialists had been developed before. However, the corporate engineering society has not been studied yet either with the reflection of the professional image nor in the communication aspect. There are just few studies which consider the engineering communication as the texts of scientific and technical style but not as an independent object to be studied. The studies in the cognitive and discursive linguistics made the methodological basis of this paper including discourse analysis, scientific discourse studies, the research in functional linguistics and genre studies, the professional language and communication and the concept structure as well. The results were obtained by techniques of discourse analysis, textual, definition and component analysis as well as the qualitative evaluation of the associative dictionary data, the corpora analysis and the analysis of the search engine data. The materials included the encyclopaedia data, dictionaries, Russian National corpora, a body of technical standards. The paper solves the following issues: the boundaries of engineering communication as a certain discourse area, the description of key institutional parameters, the boundaries of engineering discourse against the scientific discourse: purpose, participants, the genre structure. Also, the key agent of the engineering communication was defined: the boundaries of the engineer concept, at which core the image of a specialist with a university degree is. The engineering definition is updated due to the complication and recent development of the engineering activity. The professional communication in engineering sphere traditionally regarded by Russian linguists as a part of the scientific discourse was identified as a separate institutional discourse based on certain compositionally crucial parameters.

Keywords: professional communication, engineering discourse, scientific discourse, genre, communication agent, engineer, engineering, concept structure.

\section{References}

1. Golovanova E. I. Kategoriya professional'nogo deyatelya: Formirovaniye. Razvitiye. Status v yazyke [Professional category: Formation. Development. Status in language]. Chelyabinsk, Chelyab. gos. un-t Publ., 2004. 330 p. (in Russian).

2. Golovanova E. I. Professional'nyy diskurs, subdiskurs, zhanr professional'noy kommunikatsii: sootnosheniye ponyatiy [Professional discourse, subdiscourse, genre of professional communication: correlation of concepts]. Vestnik Chelyabinskogo gosudarstvennogo universiteta. Filologiya. Iskusstvovedeniye - Bulletin of Chelyabinsk State University, 2013, no. 1 (292), issue 73, pp. 32-35 (in Russian). 
3. Shattenberg S. Inzhenery Stalina: Zhizn' mezhdu tekhnikoy i terrorom v 1930-e gody [Stalin's engineers: Life between technology and terror in the 1930s]. Portal "VikiChteniye" [WikiReading Portal] (in Russian). URL: https://history.wikireading.ru/260788 (accessed 12 November 2018).

4. Avdeyeva I. B. Inzhenernaya kommunikatsiya kak samostoyatel'naya rechevaya kul'tura: kognitivnyy, professional'ny i lingvisticheskiy aspekty (teoriya i metodika obucheniya russkomu yazyku kak inostrannomu) [Engineering communication as an independent speech culture: cognitive, professional and linguistic aspects (theory and methodology of teaching Russian foreign language)]. Moscow, Bauman MSTU Publ., 367 p. (in Russian).

5. Ivanova L. I. Elektronnyy setevoy inoyazychnyy inzhenernyy diskurs i ego lingvodidakticheskiye vozmozhnosti [Electronic network second language discourse and its linguodidactical opportunities]. Izvestiya YuFU - Izvestiya SfedU. Engineering Sciences, 2010, no. 10, p. $72-75$ (in Russian).

6. Lyevina G. M. Obucheniye inostrantsev russkomu inzhenernomu diskursu kak odnoy iz sostavlyayushchikh professional'nogo obrazovaniya v rossiyskikh tekhnicheskih vuzakh. Dis. dokt. ped. nauk [Teaching of Russian engineering discourse as a component of professional qualification at Russian engineering universities. Diss. of doct. of ped. sci.]. Moscow, 2004. 369 p. (in Russian).

7. Karasik V. I. Yazykovoy krug: lichnost', kontsepty, diskurs [Language circle: personality, concepts, discourse. Diss. doct. ped. sci.]. Volgograd, Peremena Publ., 2002. 477 p. (in Russian).

8. van Dijk T. A. Yazyk. Poznaniye. Kommunikatsiya [Discourse. Comprehension. Communication. Translation from English, comp. V. V. Petrova]. Moscow, 1989. 312 p. (in Russian).

9. Kvadratura smysla: frantsuzskaya shkola diskurs-analiza [Quadrature of sense: French school of discourse analysis. Translation from French and Portuguese. The general editorship and introductory article by P. Serio; foreword by S. S. Stepanova]. Moscow, Progress Publ., 1999. 416 p. (in Russian).

10. Chernyavskaya V. E. Interpretatsiya nauchnogo teksta [Interpretation of a scientific text]. Moscow, KomKniga Publ., 128 p. (in Russian).

11. Mishankina N. A. Metafora v nauke: paradoks ili norma? [Metaphor in science: paradox or norm?]. Tomsk, TSU Publ., 2010. 281 p. (in Russian).

12. Chernyavskaya V. E. Kommunikatsiya v nauke: normativnoye i deviantnoye. Lingvisticheskiy i sotsiokulturnyy analiz [Communication in science: normative and deviant. Linguistic and sociocultural analysis]. Moscow, URSS, Librokom Publ., 2011. 270 p. (in Russian).

13. Kozhina M. N. Stilistika russkogo yazyka [The Russian language stylistics]. Moscow, Prosveshcheniye Publ., 1977. 223 p. (in Russian).

14. Shmeleva T. V. Zhanrovedeniye? Genristika? Genologiya? [Genreology? Genristika? Genology?]. Antologiya rechevykh zhanrov: povsednevnaya kommunikatsiya [Anthology of speech genres: everyday communication]. Moscow, 2007. Pp. 62-67 (in Russian).

15. Golovanova E. I. Tipologiya edinits professional'noy kommunikatsii: kognitivno-pragmaticheskiy aspect [Typology of professional communication units: a cognitive-pragmatic aspect]. Vestnik Chelyabinskogo gosudarstvennogo universiteta - Bulletin of Chelyabinsk State University, 2008, no. 9, pp. 25-28 (in Russian).

16. Frumkina R. M. Kontseptual'nyy analiz s tochki zreniya lingvista i psikhologa [Conceptual analysis from the point of view of a linguist and psychologist]. Nauchno-tekhnicheskaya informatsiya. Ser. 2. Informatsionnye protsessy i sistemy, 1992, no. 3, pp.1-9 (in Russian).

17. Gofman O. V. K voprosu o metode kontseptual'nogo analiza [To the question of the conceptual analysis method]. Kartina mira: modeli, metody, kontsepty [Picture of the world: models, methods, concepts]. Tomsk, TSU Publ., 2001. Pp. 213-217 (in Russian).

18. Popova Z. N., Sternin I. A. Kognitivnaya lingvistika [Cognitive linguistics]. Moscow, AST: Vostok-Zapad Publ., 2007. 226 p. (in Russian).

19. Smirnova O. M. K voprosu o metodologii opisaniya kontseptov [To the question of the concept description methodology]. Vestnik Nizhegorodskogo universiteta im. N. I. Lobachevskogo. Filologiya. Iskusstvovedeniye - Vestnik of Lobachevsky University of Nizhni Novgorod, 2000, no. 3, pp. 247-253 (in Russian).

20. Prokhorov A. M. Sovetskiy entsiklopedicheskiy slovar' [Soviet Encyclopedic Dictionary]. Moscow, Sov. Entsiklopediya Publ.,1988. 1600 p. (in Russian).

21. Blek D. Ekonomika. Tolkovyy slovar' [Economy. Explanatory dictionary]. Moscow, Infra-M, Ves' mir Publ., 2000. 840 p. (in Russian).

22. Rozental' D. E. Prakticheskaya stilistika russkogo yazyka [Practical Russian stylistics]. Moscow, Vysshaya Shkola Publ., 1987. 399 p. (in Russian).

23. Korobeynikov V. V., Korobeynikov A. V. Dvadtsatyy vek v biografii inzhenera: ustnaya istoriya v soprovozhdenii dokumentov [The $20^{\text {th }}$ century in an engineer's biography: an oral history illustrated with documents]. Idnakar: metody istoriko-kul'turnoy rekonstruktsii [ldnakar: methods of historical and cultural reconstruction]. Izhevsk, "3nak Izhevsk" Publ., 2010. 146 p. (in Russian).

24. Barkhudarov S. G. (Ed.) Slovar' russkogo yazyka XI-XVII vv. [Dictionary of the Russian language of the XI-XVII centuries]. Akademiya nauk SSSR. Institut russkogo yazyka. Vypusk 6 (Zipun"-lyanuariy). Moscow, Nauka Publ., 359 p. (in Russian).

25. Dal' V. I. Tolkovyy slovar' zhivogo velikorusskogo yazyka. V 4 t. [Explanatory Dictionary of the Living Great Russian Language. 4 volumes]. Saint Petersburg, Tipografiya M. O. Vol'fa Publ., 1880-1882 (in Russian).

26. Chudinov A. N. (Ed.) Slovar' inostrannykh slov, voshedshikh v sostav russkogo yazyka [Dictionary of foreign words included in the Russian language]. Saint Petersburg, Izdaniye knigoprodavtsa V. I. Gubinskogo, Tipografiya S. N. Khudekova Publ., 1894. 1004 p. (in Russian).

27. Ushakov D. N. (Ed.) Tolkovyy slovar' russkogo yazyka [Explanatory dictionary of the Russian language]. Moscow, Gos. in-t Sov. entsikl.; OGIZ; Gos. izd-vo inostr. i nats. slov. Publ., (4 t.) (in Russian).

28. Ozhegov S. I., Svedova N. Yu. (Ed.) Slovar' russkogo yazyka [Russian language dictionary]. Moscow, Sov. Entsiklopediya Publ., $1935-1940$. 846 p. (in Russian).

29. Evgenyeva A. P. (Ed.) Slovar' russkogo yazyka: v 4 t. T. 1. А-Й [Russian language dictionary: in 4 volumes. Vol. 1. A-Й]. RAN, In-t lingvistich. Issledovaniy [RAS, Institute of Linguistic Studies]. Moscow, Rus. yaz Publ., Poligrafresursy Publ., 1999. 702 p. (in Russian) 
30. Kuznetsov S. A. Bol'shoy tolkovyy slovar' russkogo yazyka [Great Dictionary of Russian language]. Saint Petersburg, Norint Publ., 1536 p. (in Russian).

31. Krysin L. P. Tolkovyy slovar' inostrannykh slov [Explanatory Dictionary of Foreign Words]. Moscow, Rus. Yaz Publ., 2000. 856 p. (in Russian).

32. Shvedova N. Yu. (ed.) Russkiy semanticheskiy slovar'. Tolkovyy slovar', sistematizirovannyy po klassam slov i znacheniy. T. 3: Imena sushchestvitel'nye s abstraktnym znacheniyem: Bytiye. Materiya, prostranstvo, vremya. Svyazi, otnosheniya, zavisimosti. Dukhovnyy mir. Sostoyaniye prirody, cheloveka. Obshchestvo [Russian semantic dictionary. Explanatory Dictionary Systematized by Classes of Words and Meanings. Vol. 3: Nouns with abstract meaning: Being. Matter, space, time. Connections, relationships, dependencies. Spiritual world. State of nature, man. Society]. Moscow, Azbukovnik Publ., 2003. 720 p. (in Russian).

33. Zakharenko E. N., Komarova L. N., Nechayeva I. V. Novyy slovar' inostrannykh slov: 25000 slov i slovosochetaniy [New dictionary of foreign words: over 25,000 words and phrases]. Moscow, Azbukovnik Publ., 2008. 1040 p. (in Russian).

34. Karaulov Yu. N., Cherkasova G. A., Ufimtseva N. V. et al. Russkiy assotsiativnyy slovar'. V 2 t. [Russian associative dictionary. In 2 volumes]. Moscow, 2002 (in Russian). URL: http://www.tesaurus.ru/dict/index.php (accessed 15 March 2018).

35. National Corpus of the Russian language (in Russian). URL: http://www.ruscorpora.ru/ (accessed 5 March 2018).

36. Golev N. D. Poiskovye sistemy Interneta kak lingvisticheskiy istochnik (na primere resheniya nekotorykh teoreticheskikh i prikladnykh voprosov russkogo slovoobrazovaniya) [The Internet search systems as a linguistic source (in the context of some theoretical and applied issues of Russian word-building]. In: Novye yavleniya v slavyanskom slovoobrazovanii. Sistema i funktsionirovaniye [New cases in Slavic word-building. System and Functioning]. Moscow, MSU Publ., 2010. Pp. 197-212. (in Russian).

Kurkan N. V., National research Tomsk Polytechnic University (pr. Lenina, 30, Tomsk, Russian Federation, 634050).

E-mail: kurkan@tpu.ru

Fadeyeva N. V., National research Tomsk Polytechnic University (pr. Lenina, 30, Tomsk, Russian Federation, 634050). E-mail: ladonadums@gmail.com.

Mishankina N. A., National research Tomsk Polytechnic University (pr. Lenina, 30, Tomsk, Russian Federation, 634050), Tomsk State University (pr. Lenina, 36, Tomsk, Russian Federation, 634050). E-mail: mna@tpu.ru. 